THE severe storm, which one of our correspondents described in our last number, will make August 12 remembered iu many parts of the South of England and South Wales. In one place in Dorsetshire, roo trees in one orchard were completely' blown down, and forty trees in another. In other places we read of cottages being umroofed, and large trees carried away; and at Cardiff, a police station is stated to have been struck by a "meteoric stone," and some damage done, whilst during the storm "a shower of small green frogs" fell.

Prof. Nr wron has sent tis an account of the shock of earthquake experienced at Boston, U.S., on the $13^{\text {th }}$ of last month. It occurred early in the morning, and though comparatively slight, was still so plainly perceptible that those who felt it had no hesitation in attributing their sensations to the proper causes. Some persons who were abroad were affected with giddiness and momentary nausea, clocks were stopped in houses, beds and windows shaken, and vessels upset.

\section{THE GOVERNMENT AND PROF. SYLVESTER}

7 ROF. SYLVESTER is one of our best mathematicians, and enjoys a European celebrity. He was, we believe, the first of the Jewish race to compete for the highest honours in the Cambridge Mathematical Tripos, setting an example which has since been followed by several distinguished men. Although he was Second Wrangler, his religious opinions disqualified him from obtaining at Cambridge the Fellowship for which he was well fitted, and which was morally his due. He had to leave the University, and after an interval, and in an evil rnoment for himself, accepted at the age of forty the post of Professor of Mathematics to the Royal Military Academy at Woolwich. Woolwich Academy, as our readers know, is the training school of officers for the Artillery and Engineers. It is one of those hybrid establishments, half regiment and half college, which are managed by well-paid officers in the Army who do not teach, and taught by ill-paid civilians who have nothing to do with the management. But, inasmuch as mathernatics formed the principal of the studies, the Professor of Mathematics was an important personage, and corresponded more nearly than any one else to the character of Head Master. He had a house and a salary of six or seven hundred a year. In 1860 a Royal Commission was appointed to inquire into the condition of Military Education in this country, and much evidence was given by the Professor as to the working of the Academy. He advocated extensive changes in the system, many of which were recommended by the Commissioners, and have since been adopted. But there was one among their many recommendations which was not suggested by the Professor, and which assuredly could not have been intended by the Commission to work retrospectively, and without due consideration, upon the teachers then in office. In altering the government and organisation of the Academy, and proposing a change in the educational staff, it was sugrested that "the Professors, Instructors, and other officials, if military men, should be appointed for seven years, at least, with the power of re-appointment. If civiliaris, their tenure of office should in no case continue after the age of 55 , unless an extension be specialiy recommended by the Governor and approved by the Secretary of State." Acting upon the Report of the Royal Commission, the War Office informed Professor Sylvester on or soon alter his $55 \mathrm{th}$ birthday that his services would be no longer required. They did not even let him stay a few werks to complete his fiteenth year of servitude, but burdied him off with a profusion of compliments, and the Treasury at their instance awarded him a retiring pension of $278 \ell$. Is. a year.

Two hundred and seventy-eight pounds one shilling a year-we may mark the precision of the calculation-is thus, according to the opinion of somebody at the Treasury, the proper compensation to be given on the abolition of his office to one of the first living mathematicians, who had spent the best fifteen years of his lifeor, as they say at Whitehall, with pitiless arcuracy, only fourteen years, ten months, and fifteen days-in the service of the nation. He was not told, when he entered the public service in the prime of life, that the tenure of his office would be thus terminable. On the contrary, the idea is entirely novel, and had never prevailed before in cur military or naval schools. We believe that Professor Sylvester is the last man in the world to set his own private claims against the p'xblic exigencies of the Royal Military Academy. But he might fairly enough object to be the victim of an experiment in organisation without being properly compensated for the consequent change in his mode of life. The Royal Commission thought that too great prominence was given at Woolwich to abstract Mathematics, and recommended the union of the two Professorships of Mathematics and Mechanics, with a view to some modifications in the system of study. But if the reformation of the Academy required the abolition of the office, surely the holder of the office deserved to be duly compensaled. It is not right for the State to treat a man of approved science and elaborate education, whom it invites into its service at the mature age of forty, on exactly the same principles of superannuation as are applied to an ordinary member of the Civil Service, who becomies a clerk, from whatever unambitious reason, at the age of seventeen. There is no parity of position between the two. If Professor Sylvester had completed his fifteenth year of service, his miniman rate of pension, according to the rules of the Civil Service, would have been $60 \%$ a year more than he was at first awarded; but the War Office and the Treasury would not even grant him this. They offered him one shilling over and above his $278 \%$. a year, and bade him God speed.

Fortunately for the Professor and for the public credit, Sir Francis Goldsmid took the matter up in the House of Commons, and gave notice that he would move an Address to the Crown that the Professor might receive as his pension, "two-thirds of the salary and emoluments enjoyed by him at the time of his removal, and humbly to assure Her Majesty that this House will make good the same." More, perhaps, he could not ask ; less it would be shabby to offer. When the establishment at Greenwich Hospital was abolished, the members were pensioned off with lavish generosity. Men who had been there barely a couple of years received their full pay and an equivalent for their house and allowances. When Haileybury College was abolished by the East Indian Government, its Professors and teachers carried with them into private life two-thirds of their official salaries. It seemed to be a necessary conclusion that the men who manage these matters in the Government can be liberal, and even generous, at the expense of charity fuxds or of distant dependencies, but bave a different measure to mete with in the case of a man of science who has given his ripe intellect to the service of this wealthy nation. We rejoice at last to hear that the First Lord of the Treasury has given the case his full, though somewhat tardy, consideration, and has removed the stigma which secmed to attach to the public conscience. A country whose wealth has increased of late so enormously, as the Chancellor of the Exchequer explained to us this Session, cannot afford to be niggardly in the treatment of its distinguished men. Any mistaken attempt in that direction would be sure to recoil upon its authors, as well as to discredit the very name of economy; and Mr. Gladstone has acted wisely as well as justly in thus rectifying at the close of the Session a lamentable departmental error.-From the Times 